\title{
Decreased MALL expression negatively impacts colorectal cancer patient survival
}

\author{
Xiaoliang Wang ${ }^{1, *}$, Junwei Fan ${ }^{1, *}$, Fudong Yu ${ }^{1, *}$, Feifei Cui ${ }^{1}$, Xing Sun ${ }^{1}$, Lin Zhong ${ }^{1}$, \\ Dongwang Yan ${ }^{1}$, Chongzhi Zhou ${ }^{1}$, Guilong Deng ${ }^{1}$, Bin Wang ${ }^{1}$, Xiaosheng $\mathbf{Q i}^{1}$, \\ Shuyun Wang ${ }^{1}$, Lei Qu ${ }^{1}$, Biao Deng ${ }^{1}$, Ming Pan ${ }^{1}$, Jian Chen ${ }^{1}$, Yupeng Wang ${ }^{1}$, Guohe \\ Song ${ }^{1}$, Huamei Tang ${ }^{2}$, Zongguang Zhou ${ }^{3}$ and Zhihai Peng ${ }^{1}$ \\ ${ }^{1}$ Department of General Surgery, Shanghai First People's Hospital, Medical College, Shanghai Jiao Tong University, Shanghai, \\ China \\ ${ }^{2}$ Department of Pathology, Shanghai First People's Hospital, Medical College, Shanghai Jiao Tong University, Shanghai, China \\ ${ }^{3}$ Department of Gastrointestinal Surgery, Laboratory of Digestive Surgery of State Key Laboratory of Biotherapy, West China \\ hospital, Sichuan University, Guo Xue Xiang, Chengdu, Sichuan China \\ * These authors have contributed equally to this work \\ Correspondence to: Zhihai Peng, email: pengzhihai@sjtu.edu.cn
}

Zongguang Zhou, email: zhou767@163.com

Keywords: biomarker; colorectal cancer; migration; survival

Received: February 09, $2015 \quad$ Accepted: February 25, 2016

Published: March 15, 2016

\section{ABSTRACT}

The aim of the present study was to determine whether MALL expression is associated with colon cancer progression and patient survival. MALL mRNA expression was reduced in the tumor tissues of $70 \%$ of the colon cancer patients and $75 \%$ of the rectal cancer patients as compared to their normal tissues. MALL protein was also significantly reduced in the tumor tissues of colon cancer patients $(P<0.001)$. Increased LOH and methylation of MALL was observed in tumor tissues as compared to normal tissues. Reduced MALL expression was associated with vessin invasion, disease recurrence and metastasis or death $(P \leq 0.027)$. Furthermore, patients with MALL-negative tumors had significantly decreased overall survival (OS) and diseasefree survival (DFS) $(P<0.008$ and $P<0.011$, respectively). Univariate analysis indicated that MALL expression was significantly associated with OS and DFS. Finally, overexpression of MALL suppressed HCT116 and SW480 cell proliferation and inhibited HCT116 migration. MALL may play a role in colorectal cancer progression as suppression of its expression in tumor tissues negatively impacts colorectal cancer patient survival. Further analyses are required to determine if reduced MALL expression is due to LOH and/or methylation.

\section{BACKGROUND}

Despite advances in treatment and screening along with increased adoption of lifestyle and nutritional changes, colorectal cancer remains a major cause of morbidity and mortality worldwide. It is the second leading cause of cancer-related death in the U.S. $[1,2]$ and Europe [3]. A similar increased incidence has been noted in China [4]. The 5-year survival rate of patients with superficial cancer (i.e., Duke's staging of colorectal cancer) was $93.2 \%$ versus those $6.6 \%$ in those with distant metastasis [5]; therefore, early diagnosis can improve colorectal cancer management.
Although colonoscopy remains the gold standard, various biomarkers, including genomic (e.g., genetic and epigenetic markers), miRNA, proteomic, and metabolomic markers, with varying sensitivities and specificities have been identified that could aid in the diagnosis of colorectal cancer $[6,7]$. Although many promising screening strategies have been reported, a biomarker of colorectal cancer incidence, development, and prognosis has yet to be identified.

In an effort to identify such a marker or panel of markers, we previously established a long serial analysis of gene expression (SAGE) database that was prepared from colon cancer tissues isolated from Chinese patients 
[8]. This analysis identified 4300 differentially expressed genes of which 2125 were upregulated and 2175were downregulated in colon cancer [8]. Upregulation of IFITM3 and downregulation of Period 3 (PER3) and phospholipase C epsilon 1 (PLCE1) were subsequently validated, and roles for each in colon cancer development have been proposed [8-10]. In addition, the expression of the T-cell differentiation protein-like, MALL (NM_005434.4), was greatly reduced in carcinoma tissue as compared to normal tissue [8]. MALL is a member of the MyD88 adapter-like (Mal) family of proteins that have role in various cancers [11].

In the present study, the reduced MALL expression was confirmed in colon and rectal cancer and normal tissues using real-time PCR analysis and immunohistochemistry, and the correlation of MALL expression levels with patient survival and clinicopathological characteristics was also evaluated. In addition, the MALL gene was analyzed for loss of heterozygosity $(\mathrm{LOH})$ and DNA methylation. Finally, the effects of MALL overexpression on cell proliferation and migration were analyzed. These studies will determine the value of MALL as a possible diagnostic and prognostic biomarker of colon cancer.

\section{MATERIALS AND METHODS}

\section{Patients and specimens}

This study included patients with colon or rectal cancer who underwent radical colectomy at the Shanghai Jiaotong University Affiliated First People's Hospital in Shanghai. Eighty patients, including 40 colon cancer patients and 40 rectal cancer patients, were included for the molecular analyses; 203 additional colon cancer patients were included for the immunochemistry analysis described below.

The normal and cancerous portions of the specimens were snap-frozen in liquid nitrogen and stored at $-70^{\circ} \mathrm{C}$. The identity of the normal and tumor tissue was confirmed by examination of hematoxylin and eosin (H\&E)-stained frozen sections of these specimens independently by two pathologists. Tumor staging was also carried out using the 6th edition of the American Joint Committee on Cancer (AJCC) staging system [12]. In addition, clinical data from all the patients were collected via medical record review. Patient follow-up was performed in accordance with the National Comprehensive Cancer Network Practice Guidelines in colon cancer [13]. Disease-free survival (DFS) and overall survival (OS) rates were defined as the interval from the initial surgery to clinically or radiologically proven recurrence/metastasis and death, respectively. The final follow-up occurred on June 29, 2008 with a median observation time for survivors of
61 months (range 9-89 months).All patients provided informed consent according to a protocol approved by the Institutional Review Board of the Shanghai First People's Hospital.

\section{Real-time PCR for MALL mRNA expression}

MALL mRNA levels were examined in 40 colon and 40 rectal cancer tissues and their normal counterparts by real-time PCR analysis with the SYBR Green RNA PCR kit (Fermentas, Shenzhen, China), according to the manufacturer's instructions and the following primers: MALL sense, 5' - CAGCCTCGTTCTTCGC-3'; MALL antisense, 5'- TTCCGTTTGTCATCCA-3' (171 bp); actin sense, 5' -ACGTGGACATCCGCAAAGAC-3'; actin antisense, 5' -CAAGAAAGGGTGTAACGCAACTA-3' (308 bp); $18 \mathrm{~S}$ RNA sense, 5'CGATGCTCTTAGCTGAGTGT $-3^{\prime}$; and $18 \mathrm{~S}$ RNA antisense, 5' - GGTCCAAGAATTTCACCTCT -3' (253 bp). MALL expression was normalized to the expression level of actin or 18S RNA, and relative expression was determined using the $\Delta \Delta \mathrm{Ct}$ method.

\section{Evaluation of $\mathrm{LOH}$}

LOH analysis was performed in 40 colon and 40 rectal cancer tissues and their normal counterparts by quantitative PCR using the following primers: MALL1 sense, 5' - GTCAGCGGACGTGACAATTAAG-3'; MALL-1 antisense, $5^{\prime}$ AGGCTTCCCAGGGAGATGTT-3'; MALL-2 sense, 5' - GCTTGCAGGACTGACATGAAC-3'; MALL-2 antisense, 5' - CACCTAAGAGGCAGGTTTCTG-3'; MALL-3 sense, 5' - ACATGCCACGATTGTTTCTG-3'; and MALL-3 antisense, 5'GAAAGCTGGAGTGGGAACAA-3'. Grossly visible normal and cancerous portions of the specimens were separated by the physicians, and the identity of the normal and tumor tissue was confirmed by examination of hematoxylin and eosin (H\&E)-stained sections of these specimens independently by two pathologists to ensure that the tumor samples were not contaminated with healthy cells. Primers were designed with the use of Oligo 6 software (NBI, Plymouth, MN, USA) and were synthesized by Shangai Sangon Biotech (Shanghai, China). Genomic DNA was extracted from frozen samples using a Qiagen DNA extraction kit (Qiagen, Hilden, Germany). The reaction mixture contained 15$\mu \mathrm{L}$ volumes with $6 \mu \mathrm{L}$ of genomic DNA $(20 \mathrm{ng} / \mu \mathrm{L}), 1.5$ $\mu \mathrm{L}$ of primers $(10 \mu \mathrm{M}$ each), and $7.5 \mu \mathrm{L}$ of Sybr Green Mix (SYBR Green RNA PCR kit, Fermentas, Shenzhen, China). Amplification was carried out under the following conditions: $95^{\circ} \mathrm{C}$ for $10 \mathrm{~min}$, followed by 42 cycles at $95^{\circ} \mathrm{C}$ for $10 \mathrm{sec}, 58^{\circ} \mathrm{C}$ for $20 \mathrm{sec}$, and $72^{\circ} \mathrm{C}$ for $60 \mathrm{sec}$, followed by 1 cycle of $95^{\circ} \mathrm{C}$ for $5 \mathrm{sec}, 55^{\circ}$ for $5 \mathrm{sec}$ and 
$95^{\circ} \mathrm{C}$ for $5 \mathrm{sec}$. The copy numbers were calculated using $\Delta \Delta c t$ method and peripheral myelin protein (PMP) as an internal reference.

\section{Bisulfite sequencing PCR (BSP) for methylation}

DNA from six colorectal cancer tissues was used to analyze the methylation status of MALL by bisulfite methylation analysis using the Methyl Code Bisulfite Conversion Kit (Invitrogen, Carlsbad, CA, USA) and following the manufacturer's instructions. Two fragments comprising $2000 \mathrm{bp}$ of the promoter region and $800 \mathrm{bp}$ of the first exon were evaluated after amplification using the following primers: 1F5' TAGTTTTGTGGTTTTGATTTGA 3'; 1R5'

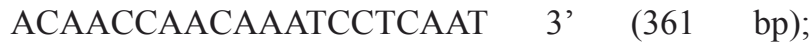
2F 5' TGAGGATTTGTTGGTTGTAG 3'; 2R 5' CCAACTCRAACAAAAAAAA 3' (270 bp). PCR was performed in a total volume of $50 \mu \mathrm{L}$ that contained $5 \mu \mathrm{L}$ of $10 \times$ buffer, $2 \mu \mathrm{L} \mathrm{MgCl}_{2}(50 \mathrm{mM}), 1 \mu \mathrm{L}$ dNTPs $(10 \mathrm{mM})$, $4 \mu \mathrm{L}$ primers ( $10 \mu \mathrm{M}$ each), $2 \mu \mathrm{L}$ DNA, $0.2 \mu \mathrm{L}$ Platinum

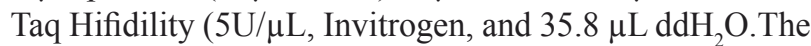
reactions were subjected to an initial incubation at $95^{\circ} \mathrm{C}$ for $3 \mathrm{~min}$ followed by 40 cycles at $95^{\circ} \mathrm{C}$ for $30 \mathrm{sec}, 53^{\circ} \mathrm{C}$ for $30 \mathrm{sec}, 68^{\circ} \mathrm{C}$ for $40 \mathrm{sec}$ with a final extension $68^{\circ} \mathrm{C}$ for 10 min. Six PCR products of 2000,1000, 750, 500, 250 , and 100 bp were obtained for each sample. The PCR products were inserted into pMD 18-T (TaKaRa, Japan), and five clones for each PCR product were sequenced using ABI 3730 sequencer (Applied Biosystems).

\section{Establishment of stable MALL expressing colorectal cells}

To determine the effects of MALL expression on colorectal cell proliferation and migration, the SW620 and HCT116 human colorectal cancer cell lines were purchased from Shanghai Institutes for Biological Sciences and infected with pGC-FU-MALL-FLAG lentiviral expression vector (Genechem) to establish stable MALL-expressing cells as previously described [10]. The inserted sequences were confirmed as NM_005434.4 using the following primers: MALL-Age I sense, GGGTACCGGTCGCCACCATGGCCTCGCCCGAC-3' and MALL- Nhe I- antisense, $5^{\prime}$-TCATCCTTGTAGTCG CTAGCGTGGTAATAGATGCTGAAG - 3'.

\section{Cell proliferation and migration assays}

Cell proliferation was determined using a MTT assay as previously described [10]. Samples were measured at $570 \mathrm{~nm}$ at $0,24,48,72,96,120,144$, and 168 $\mathrm{h}$, and a cell growth curve was plotted.

For cell migration analysis, $600 \mu \mathrm{L} /$ well of L-15 cell culture medium containing 20\% FBS (Gibco, Carlsbad, CA, USA) was placed into the lower chamber of an $8-\mu \mathrm{m}$ pore size transwell chamber. Cells in serum-free L-15 medium containing $0.1 \%$ bovine serum albumin (BSA) $\left(8 \times 10^{4}\right.$ cells $\left./ 200 \mu \mathrm{L}\right)$ were added to the top chamber. After $72 \mathrm{~h}$ at $37^{\circ} \mathrm{C}$, the migrated cells were stained with $0.1 \%$ crystal violet for $20 \mathrm{~min}$ and were counted under a microscope.

\section{Immunochemistry for MALL protein expression}

The tissues of 203 patients (86 males and 117 females) who had surgery for colon cancer at the Shanghai First People's Hospital Medical Center from January 2001 to December 2003 were analyzed for MALL protein expression. The mean age of the study participants was $65 \pm 15$ y (range 22-95 y); and 95 patients had lymph node metastases (LNM). Tissue microarrays were made from normal and tumor tissue pairs from each patient. H\&E-stained slides were screened for optimal tumor and normal adjacent tissue (at least $2 \mathrm{~cm}$ from the tumor) after which the tissue microarray slides were constructed in collaboration with Shanghai Biochip (Shanghai, China). Two cores were collected from each formalin-fixed, paraffin-embedded colon cancer tissue sample and from each normal colonic mucosa sample with a $2.0-\mathrm{mm}$ diameter punch instrument. Sections were incubated with 1:200 dilution of rabbit anti-human MALL antibody (Abgent, San Diego, CA) overnight at $4^{\circ} \mathrm{C}$, and then incubated with goat goat anti-rabbit HRP (Abcam, UK) for $45 \mathrm{~min}$ at room temperature. The sections were incubated with $\mathrm{DAB}$ (3,30-diaminobenzidine tetrahydrochloride) for $1 \mathrm{~min}$, counterstained with Mayer hematoxylin, dehydrated, and mounted. The negative control was prepared with normal tissue and without anti-MALL antibody incubation.

Immunoreactivity, based on staining intensity and extent of staining, was evaluated independently by two researchers who were blinded to patient outcome. Staining intensity for MALL was scored as 0 (negative), 1 (weak), and 2 (strong). Staining extent was scored as $0(0 \%), 1$ (1-25\%), 2 (26-50\%), 3 (51-75\%), and 4 (76-100\%), depending on the percentage of positively stained cells. The sum of the staining intensity and the staining extent scores was used as the final staining score. The specimens were divided into the following three groups, according to their overall scores: negative (0-1), weakly positive (24 ), and strongly positive (5-6) [14]. Weakly positive and strongly positive were considered as positive.

\section{Western blot analysis}

Whole-cell lysates were prepared from the cells as described previously [15], and the proteins were separated by SDS-PAGE. After transfer of the proteins, 
Table 1: Expression of MALL in normal and colon cancer tissues.

\begin{tabular}{|l|l|l|l|}
\hline Expression of MALL & Normal tissue & Tumor tissue & $P_{\text {-value }}^{\dagger}$ \\
\hline All subjects & & & $<0.001^{*}$ \\
\hline No. of subjects & 203 & 203 & \\
\hline Negative & $16(7.9)$ & $58(28.6)$ & \\
\hline Positive & $187(92.1)$ & $145(71.4)$ & \\
\hline Subjects with metastasis & & & $<0.001^{*}$ \\
\hline No. of subjects & 95 & 95 & \\
\hline Negative & $6(6.3)$ & $30(31.6)$ & \\
\hline Positive & $89(93.7)$ & $65(68.4)$ & $<0.001^{*}$ \\
\hline Subjects without metastasis & & & \\
\hline No. of subjects & 108 & 108 & \\
\hline Negative & $10(9.3)$ & $28(25.9)$ & \\
\hline Positive & $98(90.7)$ & $80(74.1)$ & \\
\hline$P$-value & 0.437 & 0.374 & $P$-value \\
\hline & LNM tissue & Tumor tissue & 0.109 \\
\hline $\begin{array}{l}\text { Subjects with metastasis who } \\
\text { provided LNM tissue }\end{array}$ & & & \\
\hline No. of subjects & 66 & 66 & \\
\hline Negative & $28(42.4)$ & $22(33.3)$ & \\
\hline Positive & $38(57.6)$ & $44(66.7)$ & \\
\hline
\end{tabular}

Data are presented as $\mathrm{n}(\%)$.

Comparison of ${ }^{\dagger}$ normal and tumor tissues; ${ }^{\star}$ patients with and without metastasis.

$P$-value are based on the ${ }^{\dagger}$ McNemar's test for association between MALL expression and tissue types, and on the ${ }^{\star}$ Person $\chi^{2}$ test for association between MALL expression and metastasis.

$* P<0.05$ indicates a significant difference.

the membranes were blocked using 5\% non-fat dry milk and incubated with primary antibodies specific for MALL, ERK, or phosphorylated ERK (p-ERK; all from CST, Boston, USA) for overnight at $4^{\circ} \mathrm{C}$. After the membranes were incubated in the appropriate horse radish peroxidaseconjugated secondary antibodies (CST; 1:5000 dilution) for 2 hours at room temperature, the proteins were detected using an enhanced chemiluminescence system (Amersham Life Sciences, Buckinghamshire, UK) according to the manufacturer's instructions. Analysis of $\alpha$-tubulin (CST) was used as a loading control. The images were analyzed quantitatively using ImageJ software (http://rsbweb.nih. gov/ij).

\section{Statistical analysis}

All experiments were performed three times independently. MALL expression data were presented by mean and standard deviation (SD). Differences between the cancer and normal tissues observed in colon or rectal cancer patients were compared using paired-t test for the global expression ( $\triangle \mathrm{CT})$ of MALL. Patients' demographics and clinical characteristics were presented by count and percentage. McNemar's test or Pearson chisquare test was performed to identify the association of MALL expression levels in different tissues. Pearson chisquare test or Fisher's exact test with Yate's correction was performed to identify the association of MALL expression levels with clinical characteristics. Univariate Cox proportional hazards models were used to evaluate the correlation of OS and DFS relative to MALL expression levels and patient characteristics. The results of Cox regression models were summarized by hazard ratio (HR) with $95 \%$ confidence interval (CI). Kaplan-Meier curves with log-rank tests represented the cumulative survival proportion for OS and DFS by MALL expression levels. All statistical assessments were two-sided and evaluated at the 0.05 level of significant difference. Statistical analyses were performed with the SPSS software for Windows, version 18.0 (SPSS Inc, Chicago, IL, USA).

\section{RESULTS}

\section{Reduced MALL expression in rectal and colon cancer tissues}

In a previously established SAGE database, we observed that the MALL gene signal was significantly reduced in carcinoma tissue as compared to normal tissue $(P<0.001)[8]$. In the present study, MALL mRNA expression was confirmed by real-time PCR analysis of normal and tumor tissues isolated from 40 patients with colon cancer and 40 patients with rectal cancer with actin 
Table 2: Associations between clinical characteristics and MALL expression in colon cancer patients.

\begin{tabular}{|c|c|c|c|}
\hline & \multicolumn{2}{|c|}{ MALL expression } & \\
\hline & Negative & Positive & \\
\hline Variables & $(n=58)$ & $(n=145)$ & $P$-value \\
\hline Age $(y)$ & & & 0.319 \\
\hline$<65$ & $20(34.5)$ & $61(42.1)$ & \\
\hline$\geq 65$ & $38(65.5)$ & $84(57.9)$ & \\
\hline Gender & & & 0.151 \\
\hline Male & $20(34.5)$ & $66(45.5)$ & \\
\hline Female & $38(65.5)$ & $79(54.5)$ & \\
\hline Tumor location & & & 0.286 \\
\hline Right colon & $30(51.7)$ & $54(37.2)$ & \\
\hline Transverse colon & $5(8.6)$ & $14(9.7)$ & \\
\hline Left colon & $4(6.9)$ & $16(11.0)$ & \\
\hline Sigmoid colon & $19(32.8)$ & $61(42.1)$ & \\
\hline T category & & & 0.639 \\
\hline $\mathrm{T} 1$ & $2(3.4)$ & $6(4.1)$ & \\
\hline $\mathrm{T} 2$ & $4(6.9)$ & $19(13.1)$ & \\
\hline $\mathrm{T} 3$ & $23(39.7)$ & $53(36.6)$ & \\
\hline $\mathrm{T} 4$ & $29(50.0)$ & $67(46.2)$ & \\
\hline $\mathrm{N}$ category & & & $0.008 *$ \\
\hline N0 & $28(48.3)$ & $80(55.2)$ & \\
\hline N1 & $13(22.4)$ & $48(33.1)$ & \\
\hline N2 & $17(29.3)$ & $17(11.7)$ & \\
\hline M category & & & 0.118 \\
\hline M0 & $50(86.2)$ & $135(93.1)$ & \\
\hline M1 & $8(13.8)$ & $10(6.9)$ & \\
\hline Vessin invasion & & & $0.027 *$ \\
\hline No & $50(86.2)$ & $139(95.9)$ & \\
\hline Yes & $8(13.8)$ & $6(4.1)$ & \\
\hline Differentiation & & & 0.214 \\
\hline Well & $29(50.0)$ & $70(48.3)$ & \\
\hline Moderate & $17(29.3)$ & $57(39.3)$ & \\
\hline Poor & $12(20.7)$ & $18(12.4)$ & \\
\hline AJCC stage & & & 0.351 \\
\hline I-II & $27(46.6)$ & $78(53.8)$ & \\
\hline III-IV & $31(53.4)$ & $67(46.2)$ & \\
\hline Recurrence and metastasis & & & $0.016 *$ \\
\hline No & $25(46.3)$ & $92(65.2)$ & \\
\hline Yes & $29(53.7)$ & $49(34.8)$ & \\
\hline Patient survival & & & $0.004 *$ \\
\hline No & $30(51.7)$ & $44(30.3)$ & \\
\hline Yes & $28(48.3)$ & $101(69.7)$ & \\
\hline
\end{tabular}

Data are presented as n (\%).

$P$-values are based on the Person $\chi^{2}$ test of Fisher's exact test.

$* P<0.05$ indicates a significant difference.

Abbreviation: AJCC, American Joint Committee on Cancer

as the internal reference. In patients with colon cancer, the global expression $(\triangle \mathrm{CT})$ of MALL was $13.16 \pm 1.37$ in tumor tissue and $11.44 \pm 0.90$ in normal tissue $(P<0.001$, Figure 1A); the relative expression $\left(2^{\Delta \Delta \mathrm{Ct}}\right)$ was $0.62 \pm 1.08$ (range $0.03-6.08$ ). In $70 \%$ of these patients, MALL tumor expression was significantly lower than in the normal tissues; in $25 \%$, no significant difference between tumor and normal tissues was detected. Similarly, in patients with rectal cancer, the global expression of MALL was $15.54 \pm 2.22$ in tumor tissue and $13.15 \pm 2.04$ in normal 
Table 3: Association between clinical characteristics and OS and DFS by univariate analysis.

\begin{tabular}{|c|c|c|c|c|}
\hline \multirow[b]{2}{*}{ Variables } & \multicolumn{2}{|l|}{ OS } & \multicolumn{2}{|l|}{ DFS } \\
\hline & HR (95\% CI) & $P$-value & HR (95\% CI) & $P$-value \\
\hline \multicolumn{5}{|l|}{ MALL expression } \\
\hline Positive vs. negative & $0.54(0.34,0.86)$ & $0.009^{*}$ & $0.56(0.35,0.88)$ & $0.013 *$ \\
\hline \multicolumn{5}{|l|}{ Age $(y)$} \\
\hline$\geq 65 v s .<65$ & $0.96(0.61,1.53)$ & 0.875 & $0.98(0.62,1.55)$ & 0.938 \\
\hline \multicolumn{5}{|l|}{ Gender } \\
\hline Male $v s$. female & $0.75(0.46,1.20)$ & 0.223 & $0.88(0.56,1.38)$ & 0.581 \\
\hline \multicolumn{5}{|l|}{ Tumor location } \\
\hline Transverse $v s$. right & $0.80(0.32,1.93)$ & 0.618 & $0.83(0.34,1.98)$ & 0.669 \\
\hline Left $v s$. right & $0.96(0.42,2.19)$ & 0.920 & $0.91(0.40,2.08)$ & 0.826 \\
\hline Sigmoid $v s$. right & $1.06(0.64,1.76)$ & 0.808 & $1.18(0.72,1.92)$ & 0.516 \\
\hline \multicolumn{5}{|l|}{ T category } \\
\hline $\mathrm{T} 2$ vs. T1 & $0.30(0.43,2.15)$ & 0.232 & $0.48(0.81,2.89)$ & 0.425 \\
\hline T3 vs. T1 & $0.95(0.22,4.09)$ & 0.944 & $1.26(0.30,5.34)$ & 0.756 \\
\hline T4 vs. T1 & $2.81(0.68,11.55)$ & 0.152 & $2.96(0.72,12.18)$ & 0.132 \\
\hline \multicolumn{5}{|l|}{$\mathrm{N}$ category } \\
\hline N1 vs. N0 & $4.02(2.18,7.43)$ & $<0.001 *$ & $2.73(1.57,4.73)$ & $<0.001 *$ \\
\hline $\mathrm{N} 2$ vs. N0 & $14.07(7.54,26.27)$ & $<0.001 *$ & $10.22(5.78,18.09)$ & $<0.001 *$ \\
\hline \multicolumn{5}{|l|}{ M category } \\
\hline M1 vs. M0 & $14.74(8.15,26.67)$ & $<0.001 *$ & $9.93(4.91,20.07)$ & $<0.001 *$ \\
\hline \multicolumn{5}{|l|}{ Vessin invasion } \\
\hline Yes $v s$. no & $4.68(2.55,8.60)$ & $<0.001^{*}$ & $4.12(2.16,7.86)$ & $<0.001^{*}$ \\
\hline \multicolumn{5}{|l|}{ Differentiation } \\
\hline Moderate $v s$. well & $2.37(1.34,4.18)$ & $0.003^{*}$ & $2.26(1.35,3.79)$ & $0.002 *$ \\
\hline Poor vs. well & $7.50(4.11,13.68)$ & $<0.001^{*}$ & $4.87(2.64,8.97)$ & $<0.001 *$ \\
\hline \multicolumn{5}{|l|}{ AJCC stage } \\
\hline III-IV vs. I-II & $6.66(3.76,11.82)$ & $<0.001 *$ & $4.24(2.59,6.92)$ & $<0.001 *$ \\
\hline
\end{tabular}

Abbreviations: OS, overall survival; DFS, disease-free survival; HR, hazard ratio; CI, confidence interval; AJCC, American Joint Committee on Cancer

$* P<0.05$ indicates a significant difference.

tissue $(P<0.001$, Figure 1B), and the relative expression was $2.85 \pm 10.80$ (range $0.002-57.48$ ). Again, $75 \%$ of the patients analyzed had significantly reduced expression in tumor tissues; no significant difference between tumor and normal tissues was detected in $15 \%$ of patients. These results are consistent with our previous SAGE analysis that shows that MALL was reduced in both colon and rectal tumors [8].

Immunohistochemical analysis of 203 normal and colon cancer pairs revealed that the distribution of MALL expression was significantly different between normal and tumor tissues $(P<0.001$; Table 1$)$. A significantly greater percentage of tumor tissues were negative for MALL expression as compared to normal tissue $(28.6 \%$ vs. $7.9 \%, P<0.001)$. This was also observed in patients with and without metastasis $(31.6 \%$ vs. $6.3 \%, P<0.001$ in subjects with metastasis; $25.9 \%$ vs. $9.3 \%, P<0.001$ in subjects without metastasis). No association between MALL expression and metastasis was found regardless of tissue types (normal tissue: $P=0.437$; cancer tissue:
$P=0.374)$. Moreover, MALL expression in LNM and cancerous tissue was not statistically different $(P=0.109$ based on the McNemar's test; Table 1).

\section{Association of reduced MALL expression in colon cancer with clinicopathologic parameters}

Of the 203 colon cancer patients whose tissues were analyzed by immunohistochemistry, 58 subjects ( 20 males and 38 females) had MALL-negative tumors (Table 1). No significant differences in age, gender, tumor location, $\mathrm{T}$ and $\mathrm{M}$ categories, tumor differentiation, and AJCC stage were observed between those patients whose tumors were MALL-positive and MALL-negative (Table 2). However, significant differences in $\mathrm{N}$ category, vessin invasion, and recurrence and metastasis were observed between MALLpositive and MALL-negative tumors. Specifically, a large percentage of MALL-negative tumors were classified as N2 as compared to MALL-positive tumors $(P<0.008)$. 
(A)

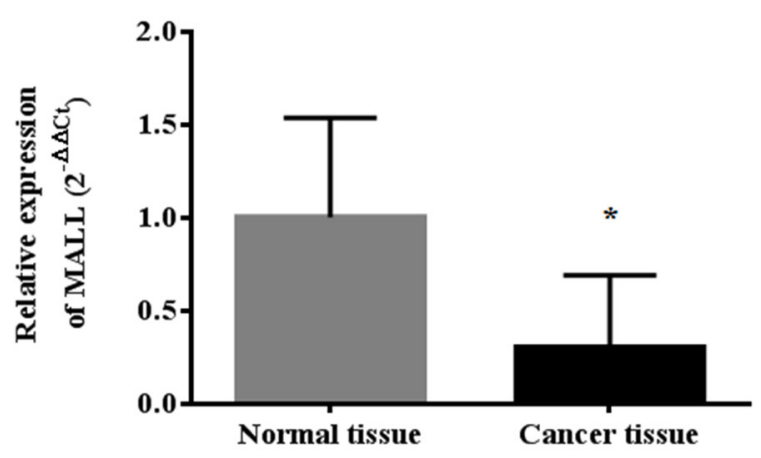

Tissue types

(B)

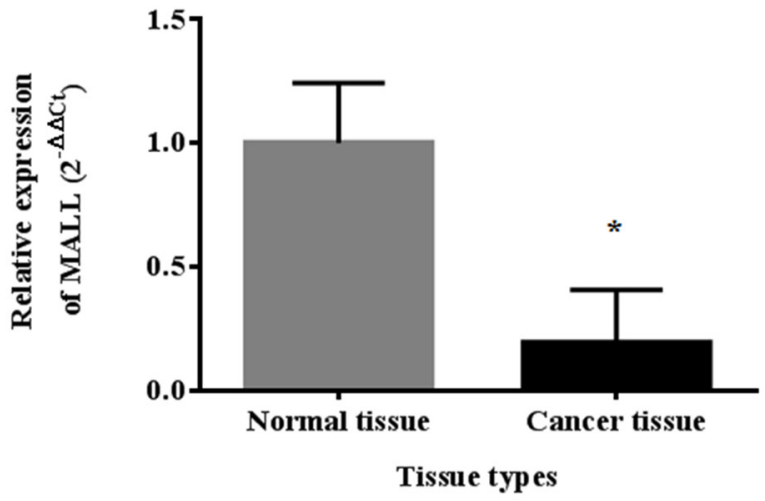

Figure 1: MALL expression in normal and cancer tissues by real-time PCR analysis. Analysis of MALL mRNA expression in A. 40 colon cancer tissues and B. 40 rectal cancer tissues with actin as the internal reference. Data are presented as mean \pm standard deviation. $* P<0.05$ indicates a significant difference between the normal and cancer tissues.

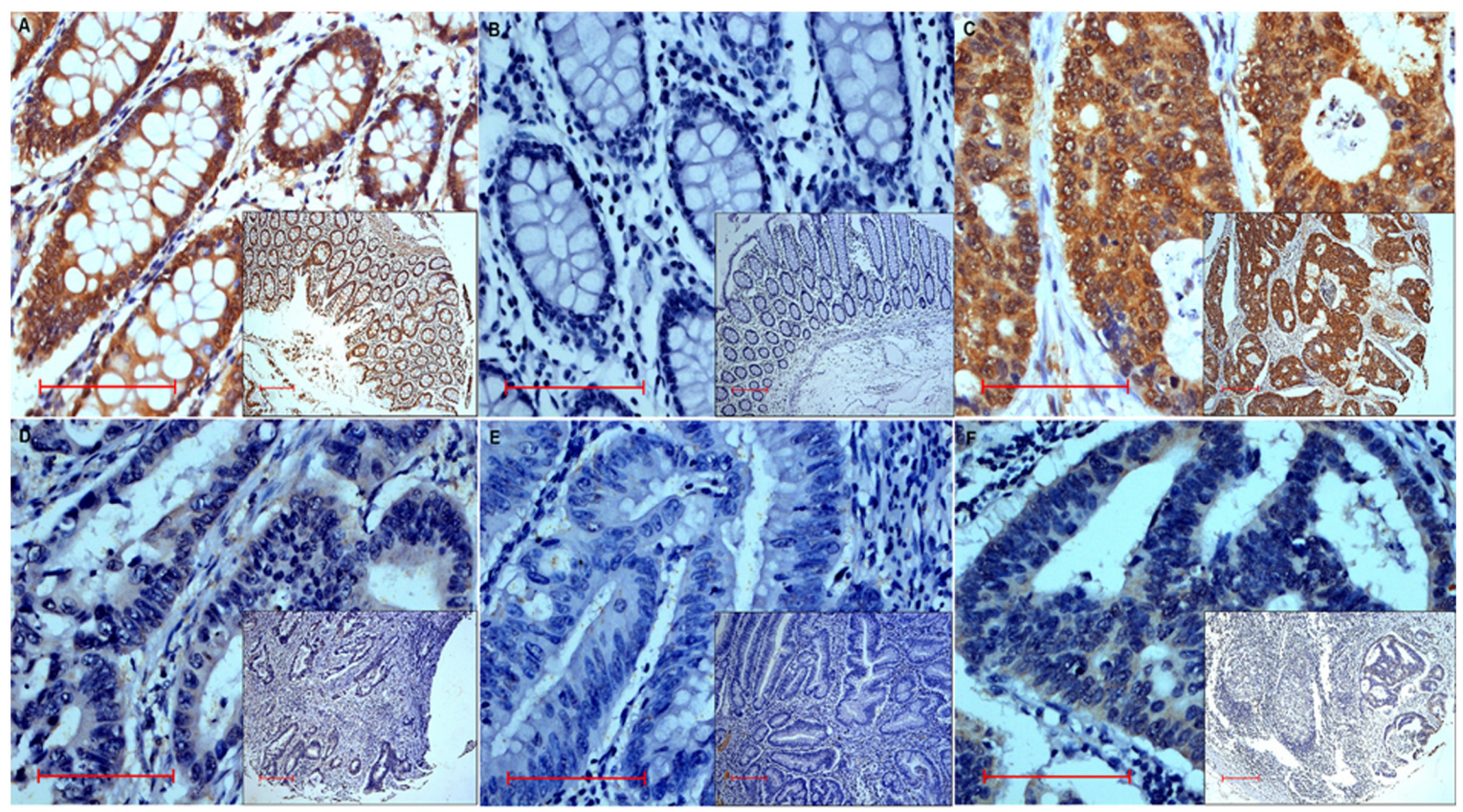

Figure 2: Representative images of MALL immunohistochemistry analysis showing MALL-positive A. Normal tissue exhibiting strongly positive expression and B. negative control in normal tissue.C.-E. Tumor tissue exhibiting strongly positive C., weakly positive D., and negative E. expression. F. Positive expression in metastatic lymph nodes tissue. Bar $=100 \mu \mathrm{m}$; original magnification $\mathrm{x} 400$ (x100 for insets). 
Table 4: Association between clinical characteristics and OS and DFS by multivariate analysis.

\begin{tabular}{|c|c|c|c|c|}
\hline \multirow[b]{2}{*}{ Variables } & \multicolumn{2}{|l|}{ OS } & \multicolumn{2}{|l|}{ DFS } \\
\hline & HR (95\% CI) & $P$-value & HR (95\% CI) & $P$-value \\
\hline \multicolumn{5}{|l|}{ MALL expression } \\
\hline Positive vs. negative & $0.68(0.39,1.18)$ & 0.168 & $0.58(0.33,1.01)$ & 0.055 \\
\hline \multicolumn{5}{|l|}{ Age (y) } \\
\hline$\geq 65 v s .<65$ & $1.15(0.69,1.91)$ & 0.217 & $1.02(0.63,1.68)$ & 0.927 \\
\hline \multicolumn{5}{|l|}{ Gender } \\
\hline Male $v s$. female & $0.73(0.44,1.20)$ & 0.731 & $0.85(0.53,1.37)$ & 0.507 \\
\hline \multicolumn{5}{|l|}{ Tumor location } \\
\hline Transverse $v s$. right & $0.85(0.34,2.18)$ & 0.854 & $0.94(0.37,2.37)$ & 0.896 \\
\hline Left $v s$. right & $0.86(0.35,2.11)$ & 0.745 & $0.79(0.33,1.86)$ & 0.586 \\
\hline Sigmoid vs. right & $1.75(0.99,3.08)$ & 0.053 & $1.81(1.05,3.13)$ & $0.034 *$ \\
\hline \multicolumn{5}{|l|}{ T category } \\
\hline $\mathrm{T} 2 v s . \mathrm{T} 1$ & $0.65(0.09,4.91)$ & 0.674 & $0.68(0.11,4.28)$ & 0.683 \\
\hline T3vs. T1 & $0.97(0.21,4.45)$ & 0.973 & $1.12(0.25,4.95)$ & 0.884 \\
\hline T4 vs. T1 & $3.12(0.71,13.79)$ & 0.133 & $3.06(0.71,13.26)$ & 0.134 \\
\hline \multicolumn{5}{|l|}{$\mathrm{N}$ category } \\
\hline N1 vs. N0 & $3.05(0.63,14.83)$ & 0.166 & $2.42(0.30,19.85)$ & 0.411 \\
\hline $\mathrm{N} 2$ vs. N0 & $8.34(1.67,41.61)$ & $0.010^{*}$ & $6.91(0.82,57.85)$ & 0.075 \\
\hline \multicolumn{5}{|l|}{ M category } \\
\hline M1 vs. M0 & $5.79(2.74,12.25)$ & $<0.001^{*}$ & $3.69(1.54,8.88)$ & $0.003^{*}$ \\
\hline \multicolumn{5}{|l|}{ Vessin invasion } \\
\hline Yes $v s$. no & $0.58(0.27,1.25)$ & 0.164 & $0.63(0.29,1.36)$ & 0.237 \\
\hline \multicolumn{5}{|l|}{ Differentiation } \\
\hline Moderate $v s$. well & $1.63(0.89,3.00)$ & 0.113 & $1.75(1.01,3.04)$ & $0.045^{*}$ \\
\hline Poor $v s$. well & $2.97(1.35,6.52)$ & $0.007^{*}$ & $2.22(1.001,4.91)$ & $0.0496^{*}$ \\
\hline \multicolumn{5}{|l|}{ AJCC stage } \\
\hline III-IV vs. I-II & $1.07(0.22,5.27)$ & 0.933 & $0.94(0.12,7.65)$ & 0.955 \\
\hline
\end{tabular}

Abbreviations: OS, overall survival; DFS, disease-free survival; HR, hazard ratio; CI, confidence interval; AJCC, American Joint Committee on Cancer

$* P<0.05$ indicates a significant difference.

Moreover, a large proportion of MALL-negative tumors had vessin invasion as compared to MALL-positive tumors $(P<0.027)$. Finally, the incidence of recurrence and metastasis or death was significantly higher in subjects with MALL-negative tumors $(P=0.016$ and $P=0.004$, respectively; Table 2). Representative images of MALLpositive normal and tumor tissues are shown in Figure 2.

\section{Association between MALL expression and colon cancer patient survival}

To evaluate the possible association between tumor MALL expression and patient survival, KaplanMeier curves with a log rank test for OS and DFS were performed (Figure 3). The 1-, 3-, and 5-year OS in subjects with MALL-negative tumors was $93 \%, 76 \%$, and $52 \%$, respectively; the OS in subjects with MALL-positive tumors was $99 \%, 88 \%$, and $57 \%$, respectively. The estimated mean OS was significantly different between patients with MALL-positive and MALL-negative tumors
(72.8 \pm 2.1 vs. $60.1 \pm 3.7$ months, respectively; $P=$ 0.008 ; Figure 3A). The 1-, 3-, and 5-year DFS in subjects with MALL-negative tumors was $89 \%, 61 \%$, and $46 \%$, respectively; the DFS in subjects with MALL-positive tumors was $93 \%, 75 \%$, and $50 \%$, respectively. The estimated mean DFS was significantly different between patients with MALL-positive and MALL-negative tumors $(67.9 \pm 2.5$ vs. $53.8 \pm 4.3$ months, respectively; $P=0.011$; Figure 3B).

As shown in Table 3, univariate Cox regression analysis revealed other factors that affect patient survival. In addition to MALL tumor expression, OS and DFS were significantly associated with $\mathrm{N}$ category, $\mathrm{M}$ category, vessin invasion status, tumor differentiation, and AJCC stage (all $P \leq 0.009$ ). DFS was significantly associated with $\mathrm{N}$ category, $\mathrm{M}$ category, vessin invasion status, tumor differentiation, and AJCC stage (all $P \leq 0.002$ ). However, multivariate analysis found no significant association between MALL expression and OS or DFS (Table 4). OS was significantly associated with $\mathrm{N}$ category, M category, and tumor differentiation (all $P \leq 0.010$ ); DFS was 
(A)

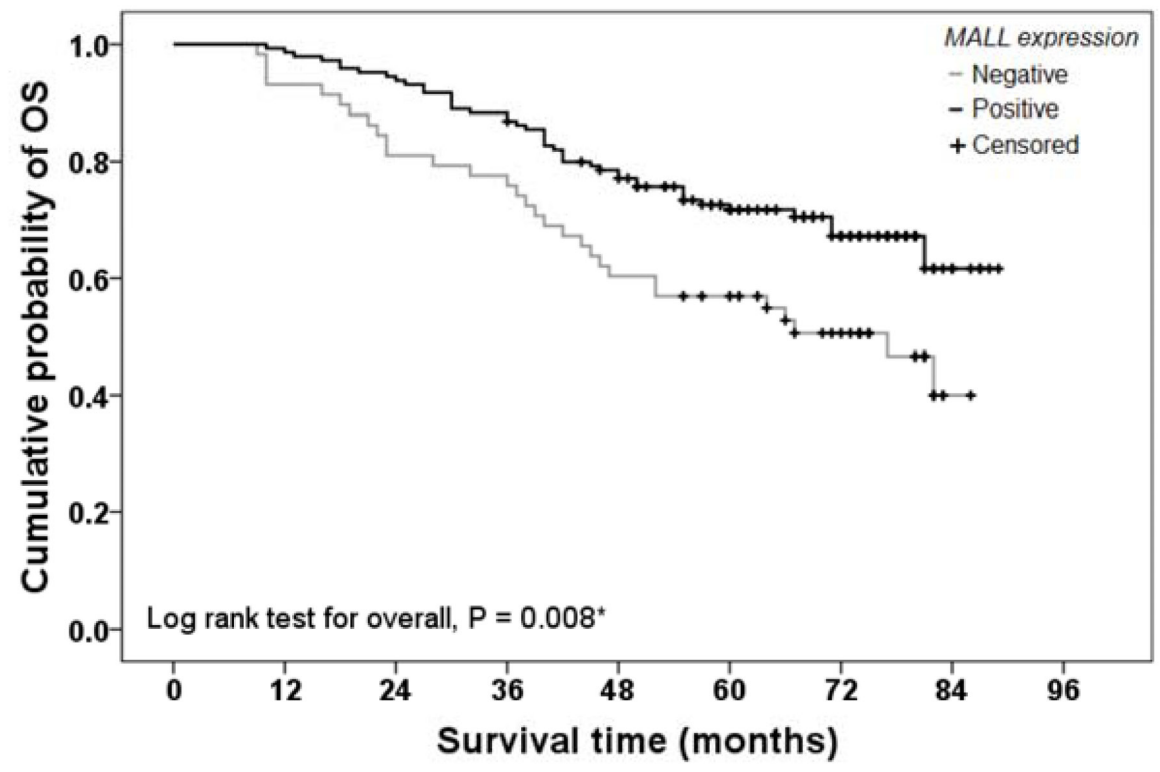

Number of subjects at risk

$\begin{array}{lccccccccc}\text { Negative } & 58 & 54 & 47 & 44 & 35 & 30 & 19 & 1 & 0 \\ \text { Positive } & 145 & 144 & 136 & 127 & 110 & 83 & 39 & 6 & 0\end{array}$

(B)

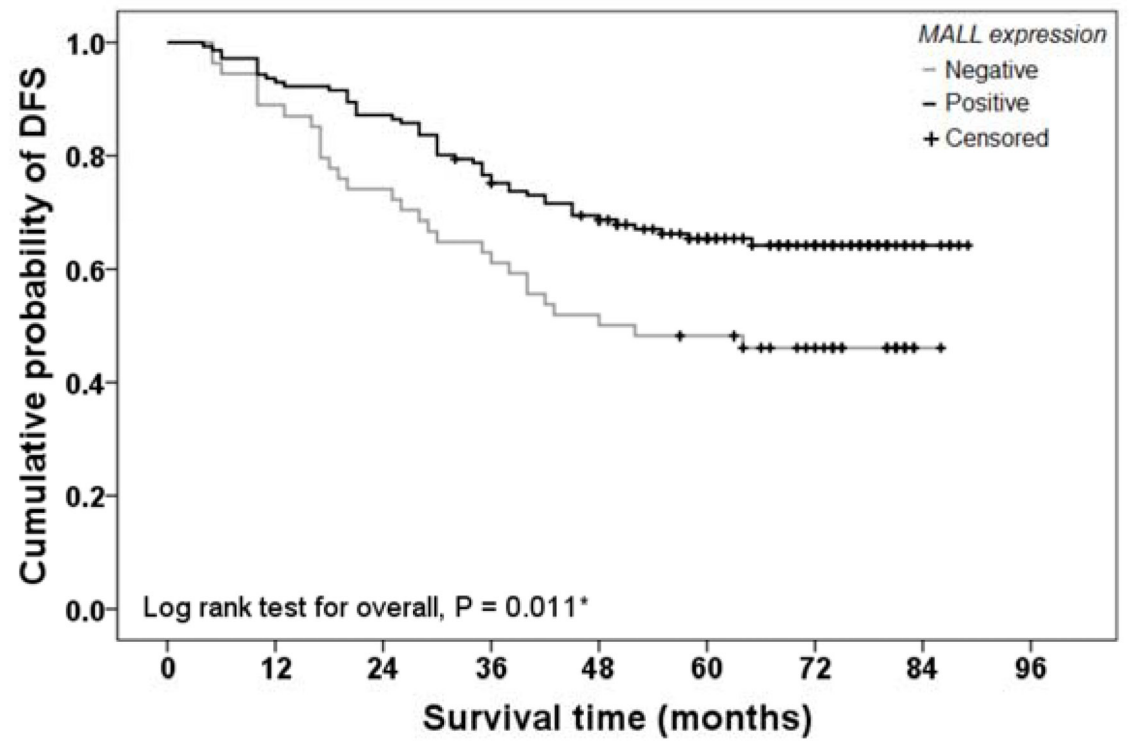

Number of subjects at risk

$\begin{array}{lccccccccc}\text { Negative } & 54 & 48 & 40 & 33 & 27 & 25 & 17 & 1 & 0 \\ \text { Positive } & 141 & 131 & 123 & 106 & 94 & 70 & 37 & 6 & 0\end{array}$

Figure 3: Colon cancer patient survival relative to MALL expression. A. Overall survival (OS) and B. disease-free survival (DFS) of 203 colon cancer patients were analyzed. 
Table 5: Methylation status of each CpG site

\begin{tabular}{|c|c|c|c|c|c|}
\hline \multirow[b]{2}{*}{ CpG site } & \multicolumn{2}{|c|}{ Normal tissue } & \multicolumn{2}{|c|}{ Cancer tissue } & \multirow{2}{*}{$P$-value } \\
\hline & Methylated & Unmethylated & Methylated & Unmethylated & \\
\hline \multicolumn{6}{|c|}{ First fragment } \\
\hline 70 & 3 & 27 & 4 & 29 & 0.789 \\
\hline 79 & 3 & 27 & 6 & 27 & 0.354 \\
\hline 92 & 4 & 26 & 6 & 27 & 0.599 \\
\hline 135 & 11 & 19 & 20 & 13 & 0.058 \\
\hline 144 & 12 & 18 & 17 & 16 & 0.360 \\
\hline 193 & 2 & 28 & 5 & 28 & 0.285 \\
\hline 221 & 1 & 29 & 2 & 31 & 0.612 \\
\hline 267 & 6 & 24 & 5 & 28 & 0.613 \\
\hline 290 & 3 & 27 & 4 & 29 & 0.789 \\
\hline 302 & 2 & 28 & 1 & 32 & 0.498 \\
\hline 305 & 1 & 29 & 4 & 29 & 0.197 \\
\hline 323 & 1 & 29 & 3 & 30 & 0.349 \\
\hline 329 & 0 & 30 & 2 & 31 & 0.171 \\
\hline 337 & 3 & 27 & 5 & 28 & 0.540 \\
\hline Total & 52 & 368 & 84 & 378 & $0.017^{*}$ \\
\hline \multicolumn{6}{|c|}{ Second fragment } \\
\hline 21 & 2 & 28 & 6 & 24 & 0.129 \\
\hline 39 & 4 & 26 & 7 & 23 & 0.317 \\
\hline 48 & 1 & 29 & 2 & 28 & 0.554 \\
\hline 74 & 1 & 29 & 5 & 25 & 0.085 \\
\hline 77 & 0 & 30 & 1 & 29 & 0.313 \\
\hline 81 & 3 & 27 & \begin{tabular}{|l|}
7 \\
\end{tabular} & 23 & 0.166 \\
\hline 93 & 3 & 27 & 7 & 23 & 0.166 \\
\hline 121 & 1 & 29 & 7 & 23 & $0.023^{*}$ \\
\hline 123 & 1 & 29 & 7 & 23 & $0.023^{*}$ \\
\hline 125 & 1 & 29 & 9 & 21 & $0.006^{*}$ \\
\hline 129 & 1 & 29 & 7 & 23 & $0.023^{*}$ \\
\hline 137 & 2 & 28 & 8 & 22 & $0.038^{*}$ \\
\hline 139 & 2 & 28 & 6 & 24 & 0.129 \\
\hline 148 & 3 & 27 & 7 & 23 & 0.166 \\
\hline 172 & 1 & 29 & 8 & 22 & $0.011^{*}$ \\
\hline 176 & 1 & 29 & 7 & 23 & $0.023^{*}$ \\
\hline 181 & 1 & 29 & 6 & 24 & $0.044^{*}$ \\
\hline 185 & 1 & 29 & 10 & 20 & $0.003^{*}$ \\
\hline 197 & 2 & 28 & 8 & 22 & $0.038^{*}$ \\
\hline 202 & 2 & 28 & 6 & 24 & 0.129 \\
\hline 206 & 2 & 28 & 9 & 21 & $0.020^{*}$ \\
\hline 209 & 2 & 28 & 7 & 23 & 0.071 \\
\hline 217 & 1 & 29 & 4 & 26 & 0.161 \\
\hline 224 & 0 & 30 & 4 & 26 & $0.038^{*}$ \\
\hline 226 & 1 & 29 & 3 & 27 & 0.301 \\
\hline 248 & 9 & 18 & \begin{tabular}{|l|}
11 \\
\end{tabular} & 19 & 0.792 \\
\hline 263 & 29 & 1 & 30 & 0 & 0.313 \\
\hline Total & 77 & 730 & \begin{tabular}{|l|}
199 \\
\end{tabular} & 611 & $<0.001^{*}$ \\
\hline
\end{tabular}

$* P<0.05$ indicates a significant difference. 
significantly associated with tumor location, M category, and tumor differentiation (all $P<0.05$; Table 4).

\section{Evaluation of MALL LOH by real-time PCR}

We next determined if the reduced MALL expression levels were due to LOH. MALL LOH was analyzed by real-time PCR analysis of normal and tumor tissues from 40 patients with colon cancer and 40 patients with rectal cancer with three different primer sets as well as PMP as the internal reference. In patients with colon cancer, the global expression $(\triangle \mathrm{CT})$ in tumor and normal tissues was $-1.50 \pm 0.40$ vs. $-1.53 \pm 0.27(P=0.621)$ of MALL-1, $-1.23 \pm 0.41$ vs. $-1.32 \pm 0.29$ of MALL-2 $(P=$

(A)

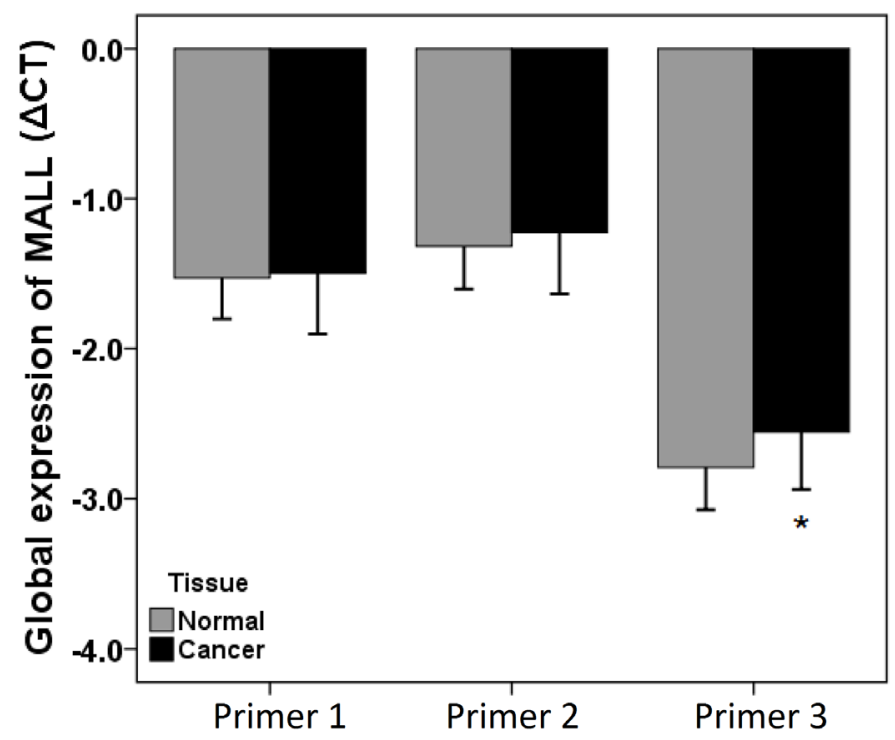

MALL

(B)

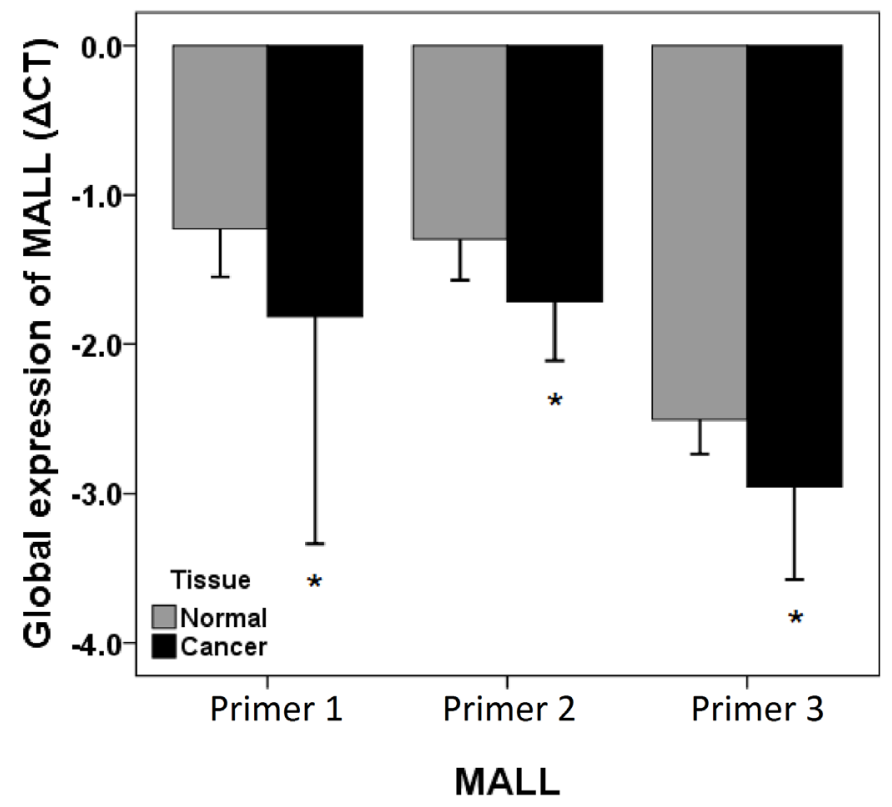

Figure 4: MALL LOH in normal and cancer tissues. MALL LOH in A. colon and B. rectal cancer tissues was determined by real-time PCR using three separate primer sets with PMP as the internal reference. Data are presented as mean \pm standard deviation of three independent experiments. $* P<0.05$ indicates a significant difference between the normal and cancer tissues. 
$0.079)$, and $-2.56 \pm 0.38$ vs. $-2.79 \pm 0.28$ of MALL-3 $(P<$ $0.001)$, respectively (Figure 4A). The relative expression $\left(2^{\Delta \Delta \mathrm{Ct}}\right.$ ) was $1.02 \pm 0.30$ (range $0.56-1.78$ ) of MALL-1, $0.96 \pm 0.22$ (range $0.59-1.65$ ) of MALL-2, and $0.88 \pm$ 0.25 (range 0.53 - 1.79) of MALL-3. In patients with rectal cancer, the global expression in tumor and normal tissues was $-1.81 \pm 1.52$ vs. $-1.23 \pm 0.32(P=0.017)$ of MALL-1, $-1.72 \pm 0.41$ vs. $-1.30 \pm 0.28$ of MALL-2 $(P<$ $0.001)$, and $-2.96 \pm 0.62$ vs. $-2.50 \pm 0.23$ of MALL-3 $(P<$ 0.001 ), respectively (Figure 4B). The relative expression was $19.71 \pm 116.28$ (range 0.88 - 736.73) of MALL-1, $1.37 \pm 0.35$ (range $0.91-2.44$ ) of MALL-2, and $1.46 \pm$ 0.45 (range $0.14-2.45$ ) of MALL-3.

\section{Methylation status results}

The methylation status of $M A L L$ was next assessed to determine if this could account for the reduced MALL expression in tumor tissues. As shown in Table 5, several $\mathrm{CpG}$ sites in tumor tissues were methylated. In the first fragment, methylation of the overall site was significantly greater in the tumor tissues as compared to that of normal tissues $(18.2 \%$ vs. $12.4 \%, P=0.017)$; similar results were obtained in the second fragment $(24.6 \%$ vs. $9.5 \%$,

(A)

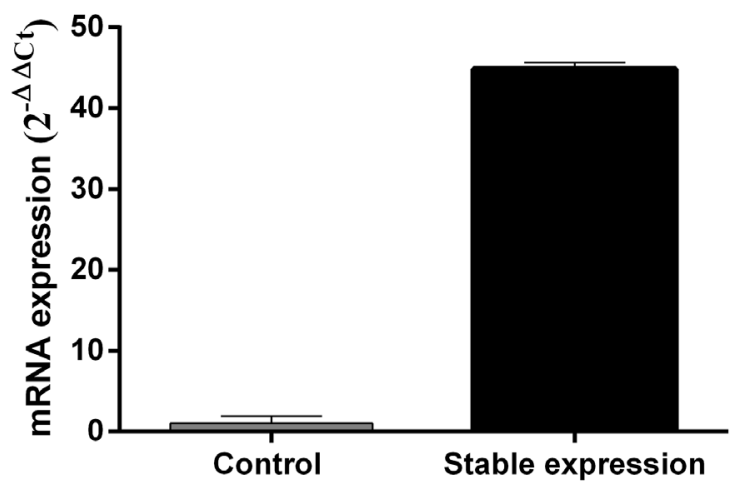

(B)

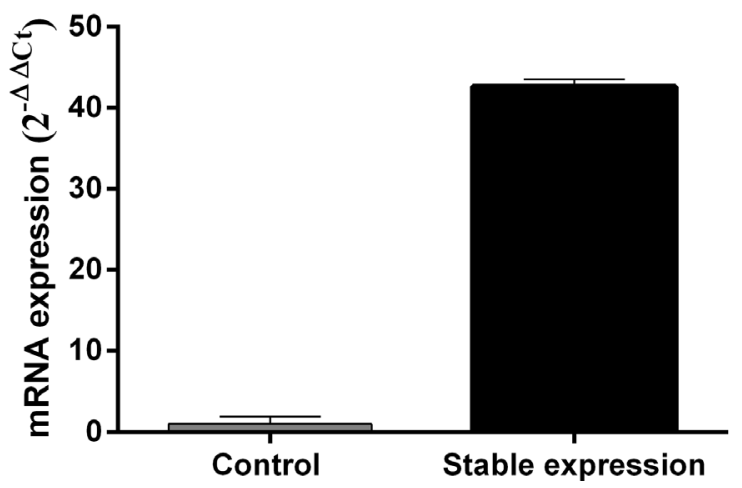

Figure 5: Levels of MALL mRNA expression after its overexpression. MALL expression in A. SW480 and B. HCT116 cell lines was determined by real-time PCR. Data are presented as mean \pm standard deviation of three independent experiments.
$P<0.001)$. In the second fragment, significantly greater methylation at sites $121,123,125,129,137,172,176$, $181,185,197,206,224$ was observed in tumor tissues as compared with that in normal tissues $(P \leq 0.044)$.

\section{Effects of MALL overexpression in colorectal cancer cell lines}

We initially measured MALL mRNA expression in eight colorectal cancer cell lines, including $\mathrm{RKO}$, HCT116, CW2, HT29, SW480, CACO2, LOVO and SW620, by RT-PCR. HCT116 and SW480 cells had the lowest expression levels of MALL and, therefore, were selected for further analysis of the effects of MALL overexpression in vitro, which was confirmed by real-time PCR analysis (Figure 5).

As shown in Figure 6A and 6B, SW480 and HCT116 cell proliferation was reduced upon MALL overexpression as compared to controls. In addition, HCT116 cell migration was markedly decreased with MALL overexpression as compared with parental and control cells (Figure 6C and 6D).

\section{MALL suppresses mitogen-activated protein kinase/extracellular signal-regulated kinase (MAPK/ERK) signaling}

Because MAPK/ERK signaling pathways are known to drive cell proliferation, survival and metastasis, we analyzed the levels of ERK phosphorylation in MALL-overexpressing SW480 and HCT116 cells to further elucidate the role of MALL in colon cancer cell proliferation and invasion. As shown in Figure 7A, decreased pERK levels were detected in both cell lines overexpressing MALL as compared with the control cells. Densitometry analysis revealed that the reduction was 0.63 \pm 0.053 in SW480 cells and $0.28 \pm 0.075$ in HCT116 cells, respectively.

We next sought to identify genes related to the $M A L L$ gene and the ERK signaling pathway. Using the BioCarta database (http://pid.nci.nih.gov/) of consensusPathDB (http://consensuspathdb.org/), we first found genes in the ERK signaling pathway. We subsequently used the PhosphoPOINT database [16] to determine if these genes have phosphorylation sites and if they interact with $M A L L$. However, our results showed these genes could not interact with the $M A L L$ gene. In contrast, the interaction between genes in the ERK MAPK signaling pathway and the MALL gene (i.e., gene-gene interaction) was identified using Ingenuity Pathway Analysis (IPA) software (http:// www.ingenuity.com/products/ipa) after removal of unrelated genes. As shown in Figure 7B, the MALL gene may interact with genes in the ERK signaling pathway via the ESR 1 gene, and there might be competitive interaction between them. 


\section{DISCUSSION}

We previously found greatly reduced expression of MALL in colon cancer tissues using a SAGE database [8]. To determine whether MALL expression is associated with colon cancer progression and patient survival, we analyzed its expression in colon and rectal cancer tissues and its association with patient clinicopathological characteristics. MALL mRNA and protein expression was

(A)

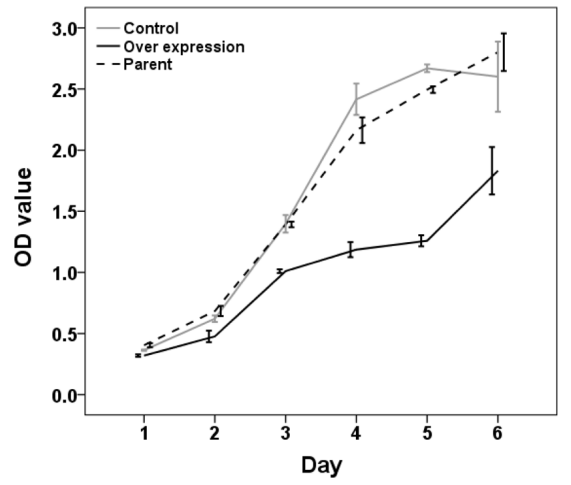

reduced in the tumor tissues analyzed, which may be due to $\mathrm{LOH}$ and/or methylation of the MALL gene. Reduced MALL expression was associated with vessin invasion, disease recurrence and metastasis or death, and patients with MALL-negative tumors had significantly decreased OS and DFS. Finally, overexpression of MALL suppressed HCT116 and SW480 cell proliferation and inhibited HCT116 migration, suggesting that reduced MALL expression contributes to colorectal cancer progression.
(B)

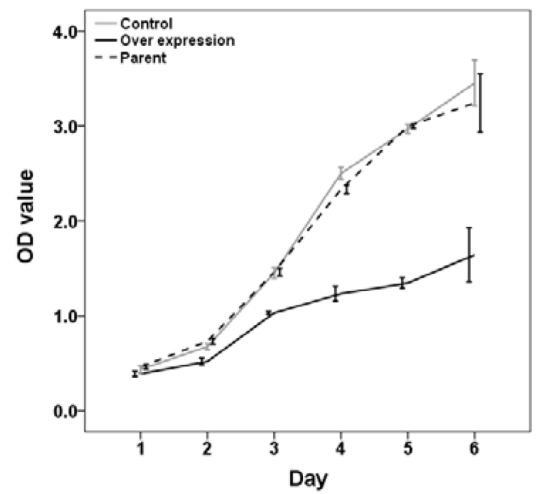

(C)

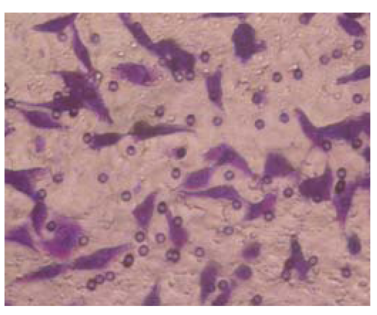

PARENT

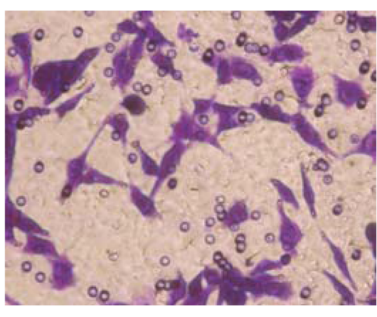

CONTROL

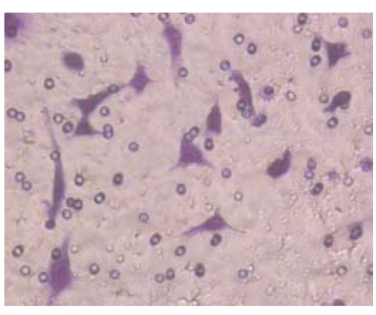

OVEREXPRESSION

(D)

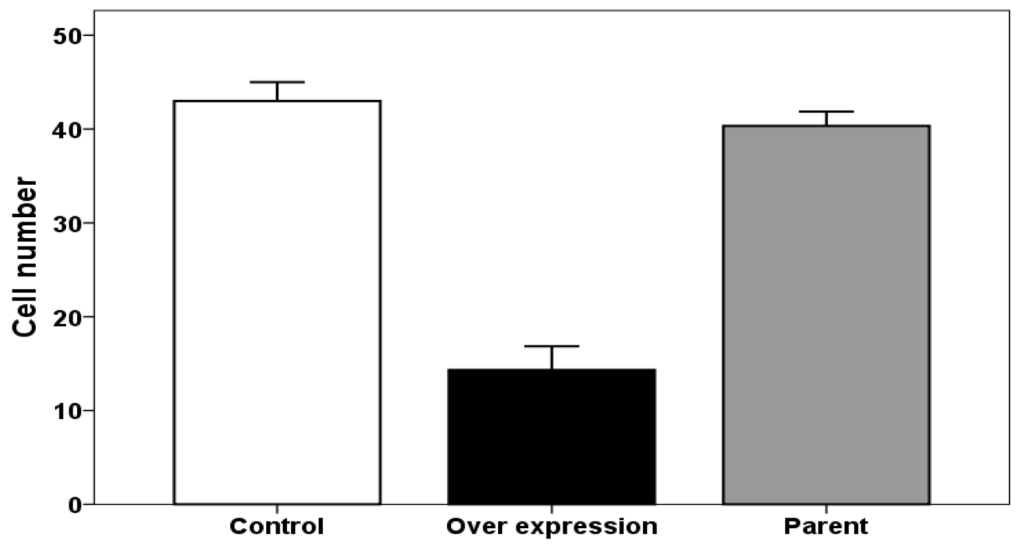

Figure 6: The effect of MALL overexpression on colorectal cell proliferation and migration. A. SW480 and B. HCT116 cell proliferation was determined in control, MALL-overexpressing and parental cells using the MTT assay at the indicate time points. C. HCT116 cell migration in control, MALL-overexpressing and parental cells. D. Quantitative analysis of the number of migrating cells in C. Data are presented as mean \pm standard deviation of three independent experiments. 
MALL is a member of the Mal family of proteins that have role in various tumors [11]. Previous reports have showed the absence of the $\mathrm{T}$ cell differentiation protein, MAL, in clear cell carcinoma as well as esophageal carcinoma although it was highly expressed in normal tissue [17, 18]. This suggests a tumor suppressor role for MAL, which was demonstrated by increased tumor cell apoptosis after ectopic expression; suppression of motility and invasion were also noted [18]. In head and neck squamous cell carcinoma, MAL expression was downregulated, and its overexpression reduced cell proliferation, cell cycle progression, and invasion and increased apoptosis [19]. Conversely, other reports have shown MAL overexpression that was associated with T cell lymphoma resistance to therapy [20]. In the present study, MALL expression was greatly reduced in colon and rectal tumor tissues as compared to normal tissues, and ectopic expression inhibited HCT116 and SW480

A

SW480

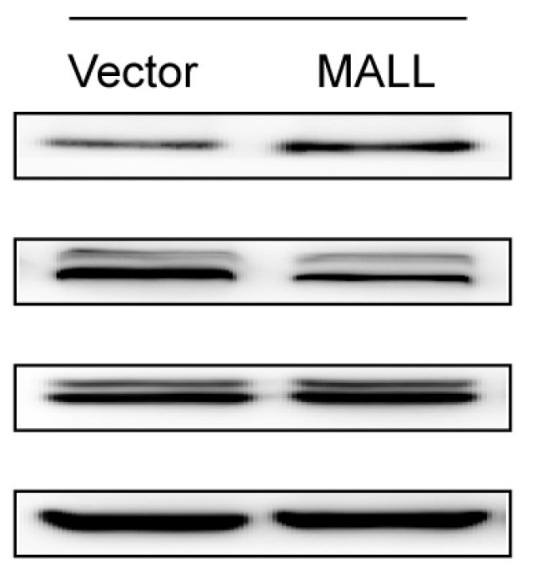

MALL

p-ERK

ERK
HCT116

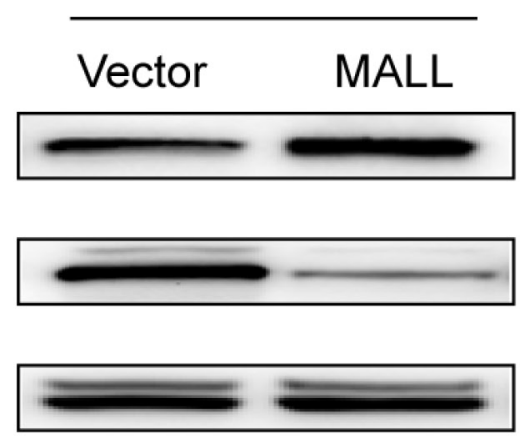

\section{Tubulin}

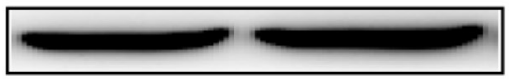

B

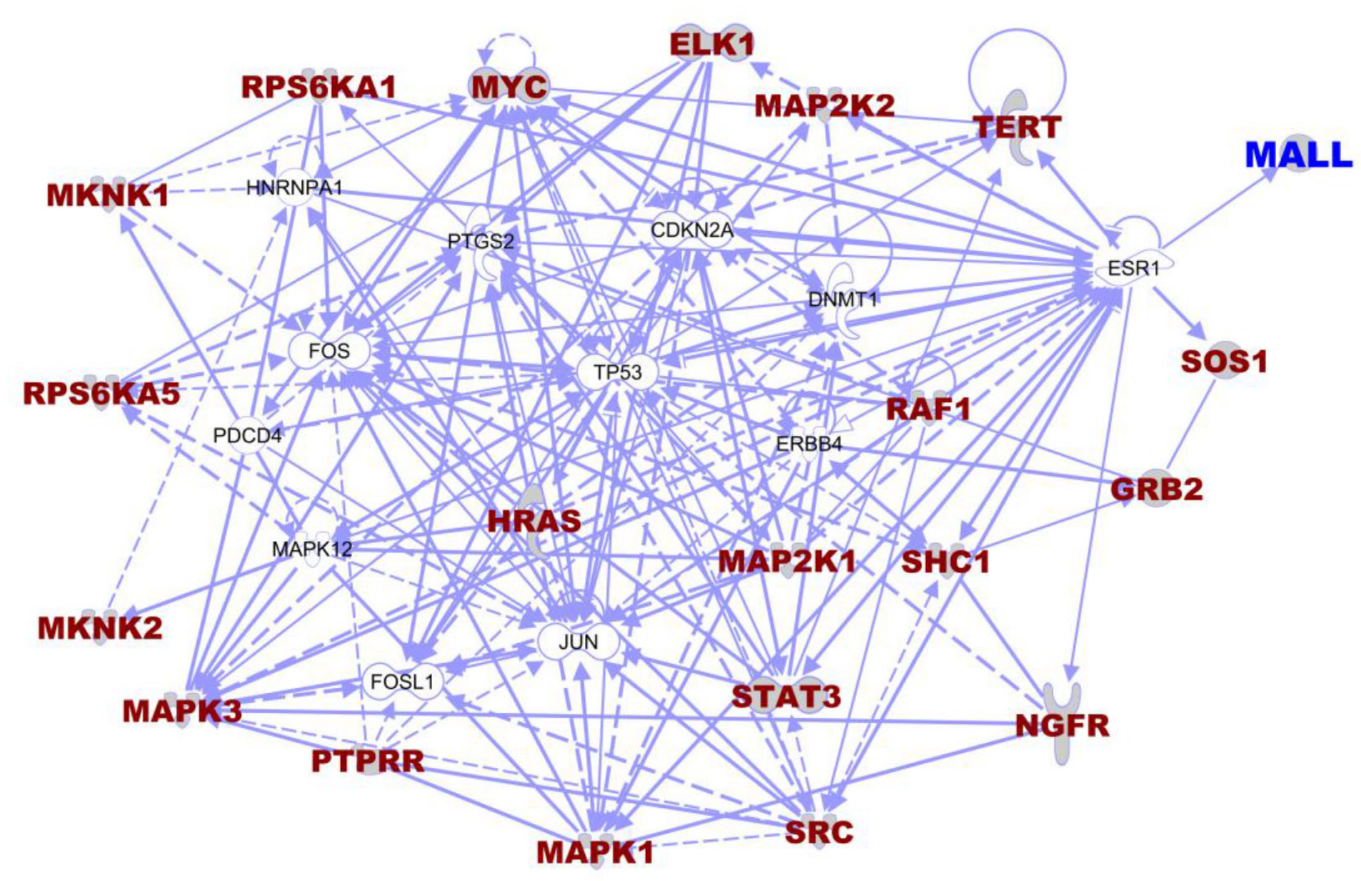

Figure 7: MALL suppresses mitogen-activated protein kinase/extracellular signal-regulated kinase (MAPK/ERK) signaling. A. p-ERK and total ERK levels were analyzed Western blot analysis in SW480 and HCT116 cells overexpressing MALL or the vector control. B. Using the BioCarta database of consensusPathDB, we found genes in the ERK signaling pathway. The interaction between genes in the ERK MAPK signaling pathway and the MALL gene were identified using IPA software after removal of unrelated genes. 
cell proliferation and HCT116 migration, suggesting that MALL may have a similar tumor suppressor function in colorectal cells.

In the present study, the mechanism by which MALL expression was repressed was explored. Increased $\mathrm{LOH}$ and methylation of the MALL gene was observed. This is consistent with previous reports in which $M A L$ promoter hypermethylation was detected in cervical disease $[21,22]$ as well as several cancers, including nonsmall cell lung cancer [23], head and neck squamous cell carcinoma [19], cervical cancer [20, 24], ovarian cancer [25], gastric cancers [26], and colorectal cancer [27]. However, further detailed analyses of the mechanisms of MALL downregulation are necessary to examine whether $\mathrm{LOH}$ and methylation are cooperative events or different mechanisms as well as to determine if these events are found in the majority of colon and rectal cancers or only specific subsets.

Epigenetic alterations are commonly observed in a variety of cancers; therefore, analysis of their modifications may represent a biomarker of disease. Determining the methylation status of $M A L$ could detect cervical lesions in high-risk human papillomavirus-positive women [28] as well as cervical cancer [20]. Furthermore, $M A L$ methylation was associated with platinum sensitivity in epithelial ovarian cancer [25]. Conversely, in gastric cancer, $M A L$ promoter hypermethylation was associated with better DFS [26]. In the present study, increased MALL methylation was noted in tumor tissues, and MALL-negative tumors were associated with reduced patient survival. Further studies will assess the association of MALL methylation status with patient prognosis to determine its value as a prognostic marker.

In the present study, overexpression of MALL suppressed HCT116 and SW480 cell proliferation and inhibited HCT116 migration. Although the precise underlying mechanism by which MALL influences these cellular activities remains unknown, we showed that MALL overexpression in SW480 and HCT116 cells reduced the phosphorylation of ERK possibly through ESR1. This suggests that MALL suppresses tumor growth and metastasis through inhibiting the ERK MAPK pathway, which is consistent with previous studies showing that cell adhesion, angiogenesis, invasion, and metastasis in colorectal cancer could be induced by ERK activation. For example, activation of the Ras/Raf/MEK/ ERK pathway induces vascular endothelial growth factor (VEGF) expression in human colorectal cancer [29]. Similarly, interactions between the cell-surface urokinase plasminogen activator receptor, an inducer of ERK activation, and integrins are crucial for tumor invasion and metastasis [30]. In addition, the expression of matrix metalloproteinase 7 (MMP7), which is involved in the early stages of intestinal tumorigenesis, is increased by epidermal growth factor (EGF)-induced MAPK signaling [31]. Furthermore, Descot et al. [32] found MAL, a MALL family protein, is the negative regulator of the EGFRMAPK signaling cascade. In addition to influencing ERK MAPK signaling, MALL may alter actin dynamics and as part of a mechanical feedback system in invading cells [33]. Alternatively, it may influence the expression of genes important for cytoskeletal organization and plasma membrane organization, including s100a4, RhoU, and Krt23, in a manner similar to that described for MAL [34].

The present study is limited due to the absence of in vivo analyses. In addition, the mechanism by which MALL influences cell proliferation and migration was not assessed. Given the role of polarity loss in cancer cell metastasis [35], further studies will assess whether MALL influences apical transport in a similar fashion as MAL $[36,37]$. Furthermore, because only six patient samples were analyzed in the methylation studies, further analyses are required to fully elucidate the exact mechanism by which MALL was downregulated.

\section{CONCLUSIONS}

Suppression of MALL expression in tumor tissues negatively affects colorectal cancer patient survival. Therefore, MALL may play a role in colorectal cancer progression and may represent a novel therapeutic related and/or diagnostic marker. Further analyses are required to determine if reduced MALL expression is due to $\mathrm{LOH}$ and/or methylation.

\section{ACKNOWLEDGMENTS}

This work was supported by the National Natural Science Foundation (No. 81472241 and No. 81270557) grant funded by the Chinese Government, and Doctoral Innovation Fund Projects from Shanghai Jiao Tong University School of Medicine (BXJ201336).

\section{CONFLICTS OF INTERESTS}

The authors declare that they have no competing interests.

\section{REFERENCES}

1. Nelson RS, Thorson AG. Colorectal cancer screening. Curr Oncol Rep. 2009; 11:482-489.

2. Labianca R, Beretta GD, Kildani B, Milesi L, Merlin F, Mosconi S, Pessi MA, Prochilo T, Quadri A, Gatta G, de Braud F, Wils J. Colon cancer. Crit Rev Oncol Hematol. 2010; 74:106-133.

3. Ferlay J, Parkin DM, Steliarova-Foucher E. Estimates of cancer incidence and mortality in Europe in 2008. Eur J Cancer. 2010; 46: 765-781.

4. Li M, Gu J. Changing patterns of colorectal cancer in China over a period of 20 years. World J Gastroenterol. 2005; 
11:4685-4688.

5. Network NCI. Colorectal Cancer Survival by Stage. 2012. Available from http/www.ncin.org.uk/publications/data briengs/colorectal_cancer_survival_by_stage.aspx

6. Sawbridge D, Probert C. Population-based screening in colorectal cancer - current practice and future developments: faecal biomarkers review. J Gastrointestin Liver Dis. 2014; 23:195-202.

7. Di Lena M, Travaglio E, Altomare DF. New strategies for colorectal cancer screening. World J Gastroenterol. 2013; 19:1855-1860.

8. Fan J, Peng Z, Zhou C, Qiu G, Tang H, Sun Y, Wang X, Li Q, Le X, Xie K. Gene-expression profiling in Chinese patients with colon cancer by coupling experimental and bioinformatic genomewide gene-expression analyses: identification and validation of IFITM3 as a biomarker of early colon carcinogenesis. Cancer. 2008; 113: 266-275.

9. Wang X, Yan D, Teng M, Fan J, Zhou C, Li D, Qiu G, Sun X, Li T, Xing T, Tang H, Peng X, et al. educed expression of PER3 is associated with incidence and development of colon cancer. Ann Surg Oncol. 2012; 19:3081-3088.

10. Wang X, Zhou C, Qiu G, Yang Y, Yan D, Xing T, Fan J, Tang H, Peng Z. Phospholipase C epsilon plays a suppressive role in incidence of colorectal cancer. Med Oncol. 2012;29:1051-1058.

11. Marazuela M, Alonso MA. Expression of MAL and MAL2, two elements of the protein machinery for raft-mediated transport, in normal and neoplastic human tissue. Histol Histopathol. 2004; 19:925-933.

12. O'Connell JB, Maggard MA, Ko CY. Colon cancer survival rates with the new American Joint Committee on Cancer sixth edition staging. J Natl Cancer Inst. 2004;96:14201425.

13. Engstrom PF, Benson AB 3rd, Chen YJ, Choti MA, Dilawari RA, Enke CA, Fakih MG, Fuchs C, Kiel K, Knol JA, Leong LA, Ludwig KA, et al. Colon cancer clinical practice guidelines in oncology. J Natl Compr Canc Netw. 2005;3:468-491.

14. Li D, Yan D, Tang H, Zhou C, Fan J, Li S, Wang X, Xia J, Huang F, Qiu G, Peng Z. IMP3 is a novel prognostic marker that correlates with colon cancer progression and pathogenesis. Ann Surg Oncol. 2009;16:3499-3506.

15. Chen J, Lu H, Yan D, Cui F, Wang X, Yu F, Xue Y, Feng $\mathrm{X}$, Wang J, Wang $\mathrm{X}$, Jiang $\mathrm{T}$, Zhang $\mathrm{M}$, Zhao S, Yu Y, Tang H, Peng Z. PAK6 increase chemoresistance and is a prognostic marker for stage II and III colon cancer patients undergoing 5-FU based chemotherapy. Oncotarget. 2015;6:355-367. doi: 10.18632/oncotarget.2803.

16. Yang CY, Chang CH, Yu YL, Lin TC, Lee SA, Yen CC, Yang JM, Lai JM, Hong YR, Tseng TL, Chao KM, Huang CY. PhosphoPOINT: a comprehensive human kinase interactome and phospho-protein database. Bioinformatics. 2008; 24: i14-20.

17. Marazuela M, Acevedo A, García-López MA, Adrados M,
Alonso MA. Expression of MAL2, an integral component of the machinery for basolateral-to-apical transcytosis, in human epithelia. J Histochem Cytochem. 2004; 52:243-252.

18. Mimori K, Shiraishi T, Mashino K, Sonoda H, Yamashita K, Yoshinaga K, Masuda T, Utsunomiya T, Alonso MA, Inoue $\mathrm{H}$, Mori M. MAL gene expression in esophageal cancer suppresses motility, invasion and tumorigenicity and enhances apoptosis through the Fas pathway. Oncogene. 2003; 22:3463-3471.

19. Tracey L, Villuendas R, Ortiz P, Dopazo A, Spiteri I, Rodríguez-Peralto JL, Fernández-Herrera J, Hernández A, Fraga J, Lombardia L, Dominguez O, Herrero J, et al. Identification of genes involved in resistance to a-interferon in cutaneous T-cell lymphoma. Am J Pathol. 2002;161:1825-1837.

20. Bierkens M, Hesselink AT, Meijer CJ, Heideman DA, Wisman GB, van der Zee AG, Snijders PJ, Steenbergen RD. CADM1 and MAL promoter methylation levels in hrHPVpositive cervical scrapes increase proportional to degree and duration of underlying cervical disease. Int J Cancer. 2013; 133:1293-1299.

21. Hesselink AT, Heideman DA, Steenbergen RD, Coupé VM, Overmeer RM, Rijkaart D, Berkhof J, Meijer CJ, Snijders PJ. Combined promoter methylation analysis of CADM1 and MAL: an objective triage tool for high-risk human papillomavirus DNA-positive women. Clin Cancer Res. 2011; 17:2459-2465.

22. Suzuki M, Shiraishi K, Eguchi A, Ikeda K, Mori T, Yoshimoto K, Ohba Y, Yamada T, Ito T, Baba Y, Baba H. Aberrant methylation of LINE-1, SLIT2, MAL and IGFBP7 in non-small cell lung cancer. Oncol Rep. 2013; 29:13081314.

23. Cao W, Zhang ZY, Xu Q, Sun Q, Yan M, Zhang J, Zhang P, Han ZG, Chen WT. Epigenetic silencing of MAL, a putative tumor suppressor gene, can contribute to human epithelium cell carcinoma. Mol Cancer 2010; 9:296.

24. Overmeer RM, Henken FE, Bierkens M, Wilting SM, Timmerman I, Meijer CJ, Snijders PJ, Steenbergen RD. Repression of MAL tumour suppressor activity by promoter methylation during cervical carcinogenesis. J Pathol. 2009; 219:327-336.

25. Lee PS, Teaberry VS, Bland AE, Huang Z, Whitaker RS, Baba T, Fujii S, Secord AA, Berchuck A, Murphy SK. Elevated MAL expression is accompanied by promoter hypomethylation and platinum resistance in epithelial ovarian cancer. Int J Cancer. 2010; 126:1378-1389.

26. Buffart TE, Overmeer RM, Steenbergen RD, Tijssen M, van Grieken NC, Snijders PJ, Grabsch HI, van de Velde CJ, Carvalho B, Meijer GA. MAL promoter hypermethylation as a novel prognostic marker in gastric cancer. Br J Cancer. 2008; 99:1802-1807.

27. Lind GE, Ahlquist T, Lothe RA. DNA hypermethylation of MAL: a promising diagnostic biomarker for colorectal tumors. Gastroenterology. 2007; 132:1631-1632. 
28. Overmeer RM, Louwers JA, Meijer CJ, van Kemenade FJ, Hesselink AT, Daalmeijer NF, Wilting SM, Heideman DA, Verheijen RH, Zaal A, van Baal WM, Berkhof J, et al. Combined CADM1 and MAL promoter methylation analysis to detect (pre)malignant cervical lesions in highrisk HPV-positive women. Int J Cancer. 2011; 129:22182225.

29. Jung YD, Nakano K, Liu W, Gallick GE, Ellis LM. Extracellular signal-regulated kinase activation is required for up-regulation of vascular endothelial growth factor by serum starvation in human colon carcinoma cells. Cancer Res. 1999; 59 :4804-4807.

30. Ahmed N, Oliva K, Wang Y, Quinn M, Rice G. Downregulation of urokinase plasminogen activator receptor expression inhibits Erk signalling with concomitant suppression of invasiveness due to loss of uPAR-beta1 integrin complex in colon cancer cells. Br J Cancer. 2003; 89: 374-384.

31. Jiang QH, Wang AX, Chen Y. Radixin enhances colon cancer cell invasion by increasing MMP-7 production via Rac1-ERK pathway. Scientific World Journal. 2014: 340271.

32. Descot A, Hoffmann R, Shaposhnikov D, Reschke M, Ullrich A, Posern G. Negative regulation of the EGFRMAPK cascade by actin-MAL-mediated Mig6/Errfi-1 induction. Mol Cell. 2009; 35: 291-304.
33. Salvany L, Muller J, Guccione E, Rørth P. The core and conserved role of MAL is homeostatic regulation of actin levels. Genes Dev. 2014;28:1048-1053.

34. Schmid D, Zeis T, Sobrio M, Schaeren-Wiemers N. MAL overexpression leads to disturbed expression of genes that influence cytoskeletal organization and differentiation of Schwann cells. ASN Neuro. 2014; 6.

35. Goldenring JR. A central role for vesicle trafficking in epithelial neoplasia: intracellular highways to carcinogenesis. Nat Rev Cancer. 2013; 13:813-820.

36. Cheong KH, Zacchetti D, Schneeberger EE, Simons K. VIP17/MAL, a lipid raft-associated protein, is involved in apical transport in MDCK cells. Pro Natl Acad Sci USA. 1999; 96:6241-6248.

37. Puertollano R, Martín-Belmonte F, Millán J, de Marco MC, Albar JP, Kremer L, Alonso MA. The MAL proteolipid is necessary for normal apical transport and accurate sorting of the influenza virus hemagglutinin in Madin-Darby canine kidney cells. J Cell Biol. 1999; 145:141-151. 